\title{
Nobelpris for in vitro-fertilisering
}

12. august 1978 ble verden gjennom et beskjedent leserbrev i The Lancet informert om at en fødsel hadde funnet sted (1). Men ikke en hvilken som helst fødsel - barnet som ble født, Louise Joy Brown, en i dag 32 år gammel frisk kvinne med egne barn, var første menneske unnfanget ved fertilisering utenfor livmoren. Det var den Cambridge-baserte fysiologen Robert Edwards og gynekologen og kirurgen Patrick Steptoe som hadde ledet teamet som sto bak og som nå fikk bekreftet effektiviteten av en metode de hadde beskrevet omtrent ti år tidligere (2). Begivenheten var en medisinsk sensasjon og en revolusjon innen behandlingen av ufrivillig barnløse par.

Robert Edwards ble født i Leeds i Storbritannia i 1925 og er utdannet innen fysiologi og genetikk. Etter mange års forskning på reproduktiv fysiologi hos dyr begynte han mot slutten av 1950-årene å interessere seg for menneskelig infertilitet. Han hadde sett hvordan barnløshet var årsak til stor sorg hos dem det rammet, og mente at det måtte kunne utvikles metoder for å hjelpe dem. Det ble begynnelsen på en forskning som skulle bli banebrytende. Edwards var den første som viste at menneskelige egg kunne gjennomgå både modning og fertilisering in vitro. Han var også førstemann til å påvise at fertiliserte humane egg kunne utvikles til embryoer og blastocytter i et tidlig stadium.

Etter hvert ønsket han å bruke egg som hadde fullført modningsprosessen in vivo, men det var ikke lett med de metoder som fantes i slutten av 1960-årene. For å få tilgang til egg måtte man den gang fjerne en liten del av eggstokken kirurgisk. Det var derfor helt avgjørende at han fikk kontakt med kirurgen og obstetrikeren Patrick Steptoe. Steptoe hadde lenge vært interessert i infertilitet og var den første som introduserte laparoskopiske metoder i Storbritannia (3). Denne teknikken gjorde at de kunne hente ut humane egg uten kirurgisk intervensjon. Den første frukten av Edwards' og Steptoes samarbeid var en artikkel i Nature i 1969, der de beskrev hvordan de ved inseminasjon in vitro av 34 laparoskopisk fjernede egg hadde lyktes med å danne sju humane zygoter (2). Det var en sensasjon som fikk bred dekning i pressen.

I 1971 fikk Edwards og Steptoe avslag fra det britiske forskningsrådet på en søknad om midler til et stort anlagt prosjekt om reproduksjonsmedisin. Begrunnelsen var at det fremdeles var for mange uavklarte etiske spørsmål knyttet til prosjektet (4). De måtte derfor utføre sin forskning ved hjelp av private donasjoner - inntil det første prøverørsbarnet var født. Da snudde imidlertid forskningsrådet umiddelbart og bevilget en stor sum (4).

I 1980 åpnet de to verdens første prøverørsklinikk, Bourn Hall Clinic utenfor Cambridge, ved hjelp av private midler. Arne Sunde og jeg ble invitert til dit i 1985 og møtte dem begge. Steptoe var av den gamle engelske skolen: Pasientene skulle ligge i en militært oppredd seng. Bare føttene skulle være dekket av teppet, og journalen skulle være plassert eksakt i sentrum. Bak ham på visitten fulgte en hale av lydige underståtter, med det norske besøket som nummer åtte. Edwards er mer folkelig og tar gjerne en uformell prat over en øl. Han har vært opptatt av å dele sine kunnskaper med flest mulig, og har reist verden rundt, også til Norge, og ansporet til videre forskning. Sammen med flere andre startet han European Society for Human Reproduction, som på sine årlige kongresser samler 9000 deltakere. I tillegg har han vært redaktør for fire høyt ansette medisinske tidsskrifter på området human reproduksjon.
Hans arbeid har etter hvert satt spor over hele verden. Det er i dag født 4,5 millioner barn etter in vitro-fertilisering (IVF), og antallet vokser med minst $300000 \mathrm{i}$ året. Selv om metoden har møtt betydelig motstand av etiske og religiøse årsaker, spesielt fra den katolske kirke, øker antallet behandlinger på verdensbasis.

I Norden kom IVF-behandling i gang i 1982, og det første barnet ble født i Göteborg i 1983. Først ute i Norge var Ullevål sykehus og Regionsykehuset i Trondheim i 1983, og den første fødselen fant sted i Trondheim i juli 1984. Hos oss var kunnskapen om denne teknisk utfordrende behandlingen sporadisk og mangelfull. Flere av oss som stelte med dette, reiste rundt i verden for å lære, til de stedene man hadde lyktes. Ingen hadde noen ferdig oppskrift, så det ble mye prøving og feiling før det ble suksess. I starten var det mye motstand også i Norge. I 1986, to år etter at det første prøverørsbarnet var født, fikk vi en egen lov om kunstig befruktning. I den første utgaven het det at man bare kunne behandle par der årsaken til infertiliteten lå hos kvinnen. I 1987 tok man i bruk en teknikk for å fryse ned embryoer som ikke ble satt tilbake til kvinnen. Det første barnet i Norden unnfanget ved hjelp av denne teknikken ble født i Trondheim.

I 1990-årene tok man i bruk en metode som gjorde at man også kunne hjelpe par der årsaken til infertiliteten lå hos mannen. Såkalt intracytoplasmatisk injeksjon av sæd (ICSI) var egnet hos par der mannen hadde nedsatt sædkvalitet. I 2005 ble det også tillatt å benytte sædceller hentet direkte ut fra testikkelen hos menn uten celler i sædvæsken. Befruktning av egg med donerte sædceller og behandling av lesbiske i parforhold er nå tillatt. I dag kan vi med hjemmel i lovverket hjelpe de aller fleste par som ønsker seg barn. I Norge er det nå 11 klinikker som tilbyr assistert fertilisering, fire private og sju offentlige, og det er snart født 20000 barn her i landet etter disse metodene.

Robert Edwards' og Patrick Steptoes arbeider var ikke bare viktige for utviklingen av nye behandlingsmetoder ved infertilitet, de to har også betydd mye for utviklingen av reproduksjonsforskningen generelt. Mens den tidligere hadde vært rettet mot å hemme reproduksjonen, ble oppmerksomheten rettet mer mot forskjellige måter å manipulere den på, fertilitetsbehandling inkludert. Både forskere, leger og mange andre gleder seg over at Robert Edwards endelig, og velfortjent, fikk Nobels ærespris i fysiologi eller medisin for sitt banebrytende arbeid.

\section{Jarl-Arne Kahn}

jarl.kahn@sthf.no

Jarl-Arne Kahn (f. 1943) er dr.med. og klinikksjef ved Sykehuset Telemark Fertilitetsklinikken Sør.

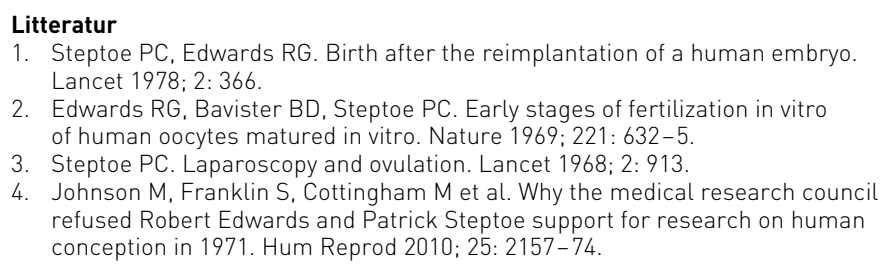

